\title{
PERBEDAAN INTENSITAS NYERI TEHNIK PEMBERIAN KOMPRES AIR HANGAT DAN AROMA TERAPI MAWAR PADA IBU BERSALIN KALA I FASE AKTIF
}

\author{
Dinda Regina Pratjna Pramita, Rahajeng Siti Nur Rahmawati, Sumy Dwi Antono \\ Prodi Kebidanan Kediri Poltekkes Kemenkes Malang \\ J1. KH. Wakhid Hasyim 64 B Kediri
}

\begin{abstract}
Childbirth pain is common. The onset of pain is due to uterine contractions, the pain felt stronger in the active phase. Management of Childbirth pain with nonpharmacological methods is very helpful for maternal mothers to reduce pain, one of them with the provision of warm water compresses and rose aromatherapy. This study aims to analyze the differences in pain intensity by giving warm water compresses on the lower back and aroma therapy of roses in the maternal mothers when I active phase in BPM Patmi Hartati Kediri Regency. The research design used was Comparative Study 2 paired samples with Pre-test and Post-test. Sampling was conducted from July 28 to August 18, 2017 with a population 27 mothers and simple random sampling technique with a sample of 26 mothers in BPM Patmi Hartatati. There are two groups that will be compared using with pre-test before treatment is given, after that post-test after treatment is given. This research using data analysis Wilcoxon Matched Pairs Test and Mann Whitney UTest. The Wilcoxon Matched Pairs Test statistic shows that the compresses warm water group with value $T_{\text {count }}(13)<T_{\text {table }}$ (17) and aromatherapy groups rose in value Tcount (9) < Tabel (17) Which means there is a difference in pain intensity before and after treatment. Based on statistical test results Mann Whitney U-Test values obtained $U_{\text {count }}(77)<U_{\text {table }}(39)$ then it can be said $\mathrm{HO}_{0}$ accepted and $\mathrm{H}_{1}$ rejected which is mean there is no difference in the intensity of pain with the provision of warm water compresses on the lower back and aroma therapy rose in maternal mothers when I Active Phase at BPM Patmi Hartati Kediri Regency.
\end{abstract}

Keywords: childbirth pain, warm water compress, rose aromatherapy.

\section{PENDAHULUAN}

Setiap wanita mengalami suatu proses melahirkan dengan cara yang berbedabeda, tergantung kesiapan tenaga mengejannya, kesiapan psikologinya, bahkan kesiapan ibu untuk menahan rasa nyeri pada saat pembukaan yaitu pada kala I fase laten sampai fase aktif, dimana kontraksi yang semakin lama semakin bertambah nyeri, jika ibu tersebut menginginkan persalinan normal. Ada juga yang menggunakan tindakan secsio caesaria bila ibu tidak menginginkan persalinan normal atau dengan tenaga sendiri yang dikarenakan ibu tidak siap dengan proses pembukaan pada kala I yang rasa nyerinya selalu bertambah.

Persalinan merupakan suatu proses janin, plasenta, dan membran keluar melalui jalan lahir dari rahim. Proses persalinan diawali dengan adanya pembukaan dan dilatasi serviks yang terjadi akibat adanya frekuensi, durasi, dan kekuatan yang teratur pada kontraksi uterus (Rohani, 2011). Menurut penelitian dari Rahma Dwi Syukrini, 2016 dalam judul peneitian "Pengaruh Aromaterapi Terhadap Tingkat Kecemasan Pada Ibu Persalinan Kala I Di Kamar Bersalin RSU Kab. Tangerang" Secara epidemiologis, gangguan kecemasan dapat terjadi pada semua persalinan baik pada persalinan primigravida maupun multigravida. Dalam sebuah penelitian ditemukan lebih dari $12 \%$ ibu yang pernah melahirkan mengatakan bahwa mereka mengalami pengalaman yang tidak menyenangkan dalam hidupnya yaitu cemas pada saat 
melahirkan. Pengeluaran hormon adrenalin akibat stress yang mereka alami dikarenakan rasa takut dan sakit mereka dapat mengakibatkan penyempitan pembuluh darah dan mengurangi aliran darah yang membawa oksigen ke rahim sehingga terjadi penurunan kontraksi rahim yang akan memperpanjang waktu persalinan. Hal ini merupakan suatu kerugian bagi seorang ibu maupun janin yang berada dalam rahim ibu.

$$
\text { Angka Kematian Ibu }
$$

Provinsi Jawa Timur pada tahun 2014 mencapai 93,52 per 100.000 kelahiran hidup. Angka ini mengalami penurunan dibandingkan tahun 2013 yang mencapai 97,39 per 100.000 kelahiran hidup (Dinas Kesehatan Provinsi Jawa Timur, 2014).

Angka Kematian Bayi (AKB) Provinsi Jawa Timur pada tahun 2013 sebesar 27,23 per 1.000 kelahiran hidup pada tahun 2014 sebesar 26,66 per 1.000 kelahiran hidup masih didominasi oleh kabupaten/kota wilayah timur dan utara (Dinas Kesehatan Provinsi Jawa Timur, 2014).

Menurut data dari Dinas Kesehatan Kabupaten Kediri jumlah ibu bersalin yang dilakukan oleh tenaga medis tahun 2015 pada Puskesmas Sidomulyo sebesar 556 pasien atau 95,70\%. Dan data persalinan dengan operasi se-Kabupten Kediri dari tahun ke tahun terus meningkat, dapat dilihat dari data pada tahun 2013 sebesar 2325 pasien, tahun 2014 sebesar 3317 pasien, dan pada tahun 2015 sebesra 3534 pasien.

Nyeri persalinan adalah rasa yang tidak menyenangkan akibat stimulasi sarafsensorik. Nyeri tersebut terdiri atas dua komponen, yaitu komponen fisiologis dan komponen psikologis. Komponen fisiologis merupakan proses penerimaan impuls tersebut menuju saraf pusat. Sementara itu, komponen psikologis meliputi rekognosi sensasi, interpretasi rasa nyeri dan reaksi terhadap hasil interpretasi nyeri tersebut (Yuliatun, Laily, 2008).
Menurut jurnal peneliti (Dian, 2012) dalam penelitian "Pengaruh Pemberian Kompres Air Hangat terhadap Rasa Nyaman dalam Proses Persalinan Kala I Fase Aktif" dalam buku (Janet Whalley. 2008) Saat ini banyak sekali cara yang digunakan dalam mengendalikan nyeri persalinan. Cara tersebut yaitu dengan tindakan medis dan tindakan non medis. Tindakan medis yang digunakan antara lain penggunaan analgesik, Penggunaan kompres hangat di punggung bawah atau perut dapat sangat menenangkan dan memberi rasa nyaman. Saat kompres menjadi dingin ganti dengan kompres hangat yang lain, hal ini sangat membantu mengurangi rasa sakit saat permulaan persalinan.

Menurut penelitian Nida'an Khofia dalam penelitian yang berjudul "Perbedaan Efektivitas Teknik Pijat (Massage Effleurage) dan Kompres Hangat Terhadap Nyeri Persalinan Kala I Fase Aktif Di Wilayah Kerja Puskesmas Bergas Kabupaten Semarang" dalam buku (Potter dan Perry, 2006). Teknik Kompres Hangat adalah Memberikan Rasa Hangat Pada Daerah Tertentu dengan menggunakan cairan atau alat yang menimbulkan hangat pada bagian tubuh untuk mengurangi rasa nyeri. Kedua teknik tersebut terdapat perbedaan dalam cara melakukannya sehingga mempunyai efek dan sensasi yang berbeda. Dari hasil penelitian didapatkan ada 28 responden, sebelum diberikan kompres air hangat sebagian besar responden mengalami nyeri sedang sebanyak 11 orang $(78,6 \%)$, sesudah diberikan kompres hangat sebagian besar mengalami nyeri sedang sejumlah 12 orang $(85,7 \%)$ Menurut penelitian (Suryani Manurung, 2013) dalam penelitian yang berjudul "Pengaruh Tehnik Pemberian Kompres Hangat Terhadap Perubahan Skala Nyeri Persalinan Pada Klien Primigravida" Penatalaksanaan dalam mengatasi nyeri persalinan berdasarkan penelitian di sembilan rumah sakit, di Amerika Serikat 
tahun 1996, sebanyak 4171 pasien, yang persalinannya ditolong oleh perawatbidan menggunakan beberapa tipe penatalaksanaan nyeri untuk mengatasi nyeri. Ibu bersalin tersebut sekitar $90 \%$ diantaranya memilih managemen nyeri dengan metode nonfarmakologis, metode tersebut adalah pilihan yang disukai oleh ibu melahirkan tehnik kompres hangat selama proses persalinan dapat mempertahankan komponen sistem vaskuler dalam keadaan vasodilatasi sehingga sirkulasi darah ke otot panggul menjadi homeostatis serta dapat mengurangi kecemasan dan ketakutan serta beradapatasi dengan nyeri selama proses persalinan 6,7 terapi kompres hangat telah terbukti meningkatkan kemampuan ibu untuk mentoleransi nyeri selama melahirkan karena efek dari panas. Dengan mengkompres di daerah sakrum ibu (punggung bawah) dapat mengurang inyeri persalinan. Hasil penelitian tersebut menunjukkan bahwa kompres hangat efektif dilakukan selama proses persalinan dan merupakan tindakan umum untuk mengatasi nyeri.

Selain kompres air hangat berdasarkan penelitian nonfarmakologi lainnya, nyeri yang dirasakan pada ibu bersalin pada kala I fase aktif dapat diberikan aroma terapi seperti aroma terapi mawar yang dapat mengurangi rasa nyeri pada ibu bersalin.

Dalam penelitian Rachmitha yang berjudul "Perbedaan Efektivitas Lama Pemberian Rose Effleurage terhadap Intensitas Nyeri Kala I Fase Aktif Pada Persalinan Normal Primigravida di Kota Semarang Tahun 2013" dalam buku Soemardiyah (2009), salah satu metode non-farmakologi yaitu aroma terapi. Menurut Koe, aroma terapi adalah metode yang menggunakan minyak atsiri untuk meningkatkan kesehatan fisik dan juga memengaruhi kesehatan emosi. Minyak atsiri merupakan komponen utama dari aroma terapi yang yang diambil dari tanaman aromatik. Sebanyak $70 \%$ pada kelompok perlakuan dua puluh menit rose effleurage mengalami penurunan skala nyeri. Beberapa minyak atsiri yang ada antara lain lavender, marjoram, nutmeg, peppermint, rose, rosemary, dan jasmine.

Meskipun metode diatas efektif untuk megurangi nyeri persalinan, tetapi praktik dalam metode ini belum pernah dilakukan di BPM Patmi Hartati Kabupaten Kediri. Metode non-farmakologi yang sering digunakan adalah metode nafas dalam.

Berdasarkan data studi pendahuluan persalinan yang telah dilakukan di BPM Patmi Hartati, Amd.Keb pada tahun 2016 bulan Desember jumlah persalinan sebesar 21 pasien yang bersalin di BPM Patmi Hartati, Amd.Keb dan ada 2 pasien bersalin yang dirujuk karena ibu bersalin tersebut tidak dapat menahan rasa sakit yang dialaminya dengan berakhir operasi SC dan 3 pasien bersalin dirujuk karena adanya resiko tinggi.

Sebagian besar ibu bersalin yang ada di BPM Patmi Hartati, Amd.Keb sering mengeluhkan nyeri pada punggung menjalar sampai ke tulang belakang pada saat adanya kontraksi yang semakin sering pada kala I maka ibu bersalin tersebut memerlukan tindakan untuk mengurangi rasa nyeri pada punggung tanpa menghilangkan kontraksi untuk pembukaan. Melihat adanya masalah tersebut maka peneliti tertarik mengambil judul tentang "Perbedaan Intensitas Nyeri dengan Pemberian Kompres Air Hangat Pada Punggung Bagian Bawah dan Aroma Terapi Mawar Pada Ibu Bersalin Kala I Fase Aktif di BPM Patmi Hartati Kabupaten Kediri”.

\section{METODE}

Penelitian ini merupakan penelitian intervensi dengan menggunakan desain penelitian Comparative Study 2 sampel berpasangan dengan Pre-test dan Post-test. Populasi dalam penelitian ini adalah seluruh seluruh ibu hamil yang mempunyai HPL pada bulan Mei 2017 di BPM Patmi Hartati, Amd.Keb Kabupaten Kediri. Sampel pada penelitian ini 
sebagian ibu yang bersalin di BPM Patmi Hartati Amd.Keb Kabupaten Kediri. Sampel pada penelitian ini adalah 26 responden, dan dibagi menjadi 2 kelompok sehingga tiap kelompok terdiri dari 13 responden. Pengambilan sampel secara Probability jenis Simple Random Sampling , yaitu Dimana peneliti membuat undian sebanyak 27 undian dan diberi penomeran untuk di undi, selanjutnya peneliti mengeluarkan 1 undian dengan cara dikocok. Kemudian peneliti menetukan kelompok 1 adalah perlakuan kompres air hangat dan kelompok 2 adalah aromaterapi mawar. Alat yang digunakan untuk mengumpulkan data tersebut adalah observasi perilaku (FLACC SCALE). Proses pengolahan data menggunakan statistik uji wilcoxon match pairs test dan uji mann whitney.

\section{HASIL PENELITIAN}

A. Intensitas Nyeri Persalinan Kala I Fase Aktif yang diberi Kompres Air Hangat Pada Punggung Bagian Bawah

Uji Wilcoxon Match Pairs Test, berdasarkan harga kritis $\mathrm{T}$ tabel wilcoxon untuk $n=13$ dengan nilai signifikansi untuk tes dua fihak 0,05 adalah 17 . Karena jenjang terkecil kurang dari $\mathrm{T}$ tabel yakni $\mathrm{T}$ hitung (13) < T tabel (17) maka $\mathrm{H}_{0}$ ditolak dan $\mathrm{H}_{1}$ diterima, artinya ada perbedaan perubahan intensitas nyeri sebelum dan sesudah diberikan kompres air hangat pada punggung bagian bawah pada ibu bersalin kala I fase aktif di BPM Patmi Hartati Kabupaten Kediri.

\section{B. Intensitas Nyeri Persalinan Kala I Fase Aktif yang diberi Aroma Terapi Mawar}

Uji Wilcoxon Match Pairs Test, analisis data pada perlakuan aroma terapi mawar diperoleh $\mathrm{T}$ hitung yakni 9 , kemudian $\mathrm{T}$ hitung dibandingkan dengan $\mathrm{T}$ tabel. Berdasarkan harga kritis $\mathrm{T}$ tabel wilcoxon untuk $n=13$ dengan nilai signifikansi untuk tes dua fihak 0,05 adalah 17. Karena jenjang terkecil kurang dari $\mathrm{T}$ tabel yakni $\mathrm{T}$ hitung (9) $<\mathrm{T}$ tabel (17) maka $\mathrm{H}_{0}$ ditolak dan $\mathrm{H}_{1}$ diterima, artinya ada perbedaan perubahan intensitas nyeri sebelum dan sesudah diberikan aroma terapi mawar pada ibu bersalin kala I fase aktif di BPM Patmi Hartati Kabupaten Kediri.

\section{Perbedaan Kompres Air Hangat dan Aroma Terapi Mawar Terhadap Intensitas Nyeri Persalinan}

Setelah diberikan kompres air hangat dan aromaterapi mawar sebagian besar responden mengalami nyeri sedang. Dari hasil pengumpulan data, dilakukan perhitungan menggunakan rumus uji Mann Whitney. Berdasarkan uji statistik, didapatkan nilai $U$ yang terkecil sebesar 77 dan $U$ tabel sebesar 39 sehingga $U$ hitung > U tabel dan hasil penghitungan dengan menggunakan SPSS 16.0 diperoleh nilai $\mathrm{Z}-0,396$ sedangkan nilai Sig atau $\rho$ value didapatkan hasil nilai Asymp.Sig. (2- tailed) $\rho$ 0,692 dimana nilai $\rho>0,05$ dengan demikian dapat disimpulkan bahwa Ho diterima dan $\mathrm{H}_{1}$ ditolak yang berarti tidak ada perbedaan intensitas nyeri dengan pemberian kompres air hangat pada punggung bagian bawah dan aroma terapi mawar pada ibu bersalin kala I Fase Aktif di BPM Patmi Hartati Kabupaten Kediri.

\section{PEMBAHASAN \\ Intensitas Nyeri Persalinan Sebelum Diberikan Kompres Air Hangat}

Dalam penilaian intensitas nyeri yang dilakukan pada kelompok kompres air hangat didapatkan hasil sebelum pemberian skala nyeri 6 ada 4 responden $(30,7 \%)$ kategori nyeri sedang, skala nyeri 7 ada 3 responden $(23,1 \%)$ kategori nyeri berat, dan skala nyeri 8 ada 1 responden $(7,7 \%)$ kategori nyeri berat. Dari uraian tersebut didapatkan intensitas terbanyak adalah skala nyeri 5 dengan 5 reponden 
$(38,4 \%)$ masuk kedalam kategori nyeri sedang.

Hal ini sesuai dengan penelitian yang dilakukan oleh Nida'an (2015) Penelitian ini melakukan penilain terhadap $28 \mathrm{ibu}$ bersalin kala I fase aktif dengan cara accidental sampling. Didapatkan hasil pada kelompok intervensi kompres hangat sebelum intervensi nilai pada nyeri sedang $78,6 \%$ dan nyeri berat $21,4 \%$. Sedangkan pada kelompok intervensi teknik pijat (massage) nilai nyeri sedang 78,6\% dan nyeri berat $21,4 \%$, sama-sama memiliki nilai nyeri sedang. Penelitian Dwi Ratnasari (2015) menunjukan nyeri persalinan pre test dengan prosentase tertinggi masuk kategori nyeri sedang sejumlah 7 responden $(58.3 \%)$, sedangkan prosentase terendah denga kategori nyeri berat sejumlah 5 responden (41.7\%).

Oleh karena itu perlu ada managemen pengendalian rasa nyeri persalinan dalam proses persalinan. Kondisi yang dialami setiap ibu bersalin berbeda-beda, ibu bersalin primigravida dan multigraavida mempunyai intensitas nyeri yang sama. Hal tersebut dikarenakan adanya bebrapa faktor. Peran tenaga kesehatan dalam hal ini sangat penting, karena penanganan yang tepat akan mempengaruhi keadaan ibu dan janin. Salah satu metode untuk menurunkan dan mengendalikan rasa nyeri pada persalinan kala I fase aktif dengan metode nonfarmakologi adalah dengan penggunaan aplikasi dari kompres air hangat. Kompres dengan air hangat akan meningkatkan aliran darah dan meredakan nyeri. Sehingga i b u bisa merasa nyaman dan relaks menghadapi persalinan.

\section{Intensitas Nyeri Persalinan Sesudah Diberikan Kompres Air Hangat}

Dari hasil pengumpulan data dan pengol Dijabarkan dalam penilaian intensitas nyeri yang dilakukan pada kelompok kompres air hangat didapatkan hasil sebelum pemberian perlakuan adalah skala nyeri 3 ada 2 responden $(15,4 \%)$ kategori nyeri ringan, 4 ada 3 responden $(23,1 \%)$ kategori nyeri sedang, skala nyeri 5 ada 5 responden $(38,5 \%)$ kategori nyeri sedang, skala nyeri 6 ada 1 responden $(7,7 \%)$ kategori nyeri sedang, dan skala nyeri 7 ada 2 responden $(15,4 \%)$ kategori nyeri berat. Dari uraian tersebut didapatkan intensitas terbanyak adalah skala nyeri 5 dengan 5 responden $(38,5 \%)$ kategori nyeri sedang.

Berdasarkan penelitian yang dilkukan oleh Nida'an (2015) uji t dependen, didapatkan nilai $\mathrm{t}$ hitung sebesar 4,947 dengan p-value sebesar 0,0001. Terlihat bahwa $p$ - value $0,0001<\quad(0,05)$, ini menunjukkan bahwa terdapat perbedaan yang signifikan skala nyeri persalinan kala I fase aktif sebelum dan sesudah diberikan kompres hangat pada ibu bersalin di wilayah kerja Puskesmas Bergas Kab. Semarang.

Penelitian yang dilakukan oleh Sari (2010) yang bertujuan untuk mengukur ada atau tidaknya penurunan nyeri dengan metode kompres hangat pada ibu bersalin kala I fase aktif. Desain yang digunakan adalah quasi eksperimen yang bersifat one group pretest dan postest. Intensitas nyeri yang dirasakan responden pada kelompok kompres air hangat ini yaitu responden yang berusia 20-35 tahun sebagian besar mengalami nyeri sedang sebanyak 7 responden $(53,8 \%)$.

Dalam penelitian yang dilakukan oleh Potter (2005) berdasarkan karakteristik menurut kelompok umur sebagian besar 26-30 tahun sebanyak 6 responden (20\%). Perbedaan perkembangan yang ditemukan diantara kelompok usia ini dapat mempengaruhi bagaimana ibu bersalin bereaksi terhadap nyeri.

Nyeri yang terjadi dapat mempengaruhi kondisi ibu bersalin dapat dilihat dari faktor fisik dan psikologi yaitu gender, umur, kelelahan, memori, etnik, nilai budaya, kecemasan, ketakutan, lingkungan tempat bersalin dan 
pelayanan yang diberikan oleh tim kesehatan (Maryunani, 2010).

Metode nonfarmakologi seperti kompres hangat dapat menjadikan tubuh terasa rileks karena kehangatan air yang membantu pembuluh darah yang melebar sehingga aliran darah lancar. Kompres hangat ini sangat bermafaat dalam menurukan nyeri persalinan karena kompres hangat dapat meningkatkan suhu kulit, melancarkan sirkulasi darah, dan mengurangi spasme otot, menghilangkan sensasi nyeri memberikan ketenangan dan kenyamanan pada nyeri saat persalinan.

\section{Intensitas Nyeri Persalinan Sebelum Diberikan Aroma Terapi Mawar}

Dijabarkan dalam penilaian intensitas nyeri sebelum diberikan perlakuan aroma terapi mawar didapatkan hasil skala nyeri pada responden sebagai berikut skala nyeri 4 ada 1 responden $(7,7 \%)$ kategori nyeri sedang, skala nyeri 5 ada 4 responden $(30,7 \%)$ mengalami nyeri persalinan sedang, skala nyeri 6 ada 2 responden $(15,4 \%)$ kategori nyeri sedang, skala nyeri 7 ada 3 responden $(23,1 \%)$ kategori nyeri berat, dan skala nyeri 8 ada 3 responden $(23,1 \%)$ kategori nyeri berat. Dan yang terbanyak adalah skala nyeri 5 dengan 4 responden

Penelitian yang dilakukan oleh Sisca Dewi (2014), frekuensi tingkat nyeri responden yaitu sebelum diberikan intervensi (pre test) aromaterapi lavender, rata-rata intensitas nyeri yang dirasakan responden adalah 7,65 dengan rincian sebanyak 17 orang $(85 \%)$ merasakan nyeri berat, 3 orang $(15 \%)$ merasakan nyeri sedang, dan tidak ada yang merasakan nyeri ringan dan sangat berat (tidak terkontrol).

Faktor nyeri dipengaruhi oleh budaya, usia, emosi, paritas, support system, pengalaman yang telah diperoleh sebelumnya sehingga individu tersebut mampu membantu dirinya mengurangi ketakutan, tekanan dan stres persalinan, persiapan persalinan dan lama persalinan untuk mencegah keletihan (Andarmoyo, Suharti. 2013).

Hasil dari penelitian yaitu diketahui bahwa hampir seluruh responden kelompok Aroma Terapi Mawar adalah berusia 20-35 tahun yaitu sebagian responden mengalami tingkat nyeri sedang 5 responden $(38,4 \%)$ dan nyeri berat 5 responden $(38,4 \%)$.

Oleh karena itu, perlu adanya perlakuan khusus dari tenaga kesehatan terutama bagi bidan yang menangani persalinan dapat mengaplikasikan metode non-farmakologi salah satunya adalah aroma terapi minyak esensial bunga mawar. Aromaterapi memunculkan bau yang menyenangkan akan menciptakan perasaan tenang, senang, dan rileks serta dapat memperlancar aliran darah. Sehingga dapat mengurangi nyeri dalam persalinan.

\section{Intensitas Nyeri Persalinan Sesudah Diberikan Aroma Terapi Mawar}

Dijabarkan dalam penilaian intensitas nyeri sesudah diberikan perlakuan aroma terapi mawar didapatkan hasil skala nyeri pada responden sebagai berikut skala nyeri 3 ada 3 responden $(23,1 \%)$ kategori nyeri ringan, skala nyeri 4 ada 1 responden $(7,7 \%)$ kategori nyeri sedang, 5 ada 4 responden $(30,8 \%)$ kategori nyeri sedang, skala nyeri 6 ada 3 responden $(23,1 \%)$ kategori nyerisedang, dan skla nyeri 7 ada 2 responden $(15,4 \%)$ mengalami nyeri berat.

Penelian yang dilakukan oleh Sisca Dewi (2014), desain penelitian ini adalah experimental dengan rancangan one group pretest-posttes without control kepada 20 orang. Uji statistik menggunakan paired t-test diperoleh nilaii $p$ value $=0,000 \quad(p$ value $<0,05)$ artinya $\mathrm{t}$ erdapat pemberian aromaterapi lavender secara inhalasi mampu menurunkan intensitas nyeri persalinan fisiologis pada primipara inpartu kala satu fase aktif. 
Penelitian yang dilakukan Wening,dkk (2013), pada pasien pasca SC sebanyak 32 resounden dengan desain preeksperimental one group pretest - postest didapatkan hasil skala nyeri sebelum pemberin aromaterapi lavender secara inhalasi rata-rata skala nyeri 5,44 (kisaran 2-9), sesudah pemberian aromaterapi skala nyeri 4,31 (kisaran 1-7), $\rho=0,001$. Disimpulkan terdapat perbedaan intensitas nyeri sebelum dan sesudah pasca SC setelah pemberian aroma terapi lavender.

Dari hasil yang didapatkan aroma terapi mawar yang diberikan kepada ibu bersalin dapat menurunkan intensitas skala nyeri. Hal ini dikarenakan kandungan yang terdapat didalam ekstrak aromaterapi mawar yang dipanaskan dengan tungku pemanas menguap sehingga tercium aroma wangi yang menimbulkan efek tenang, merelaksasi pikiran, menyegarkan, dan menurunkan ketengangan otot pada ibu bersalin kala I fase aktif.

\section{Perbedaan Intensitas Nyeri Persalinan yang Diberikan Kompres Air Hangat dan Aroma Terapi Mawar}

Berdasarkan penelitian yang dilakukan oleh Virgin (2013) tentang perbedaan intensitas nyeri antara kompres panas dan kompres dingin pada ibu bersalin dengan desian control group desain. Didapatkan hasil dengan uji mann-whitney dimana kompres panas $t$ hitung (15) < t tabel (17) dan untuk kompres dingin $\mathrm{t}$ hitung (9) $<\mathrm{t}$ tabel (17) maka dapat disimpulkan bahwa tidak ada perbedaan intensitas nyeri persalinan yang diberikan kompres panas dan kompres dingin.

Berdasarkan penelitian yang dilakukan oleh Baroroh (2016) tentang perbedaan perubahan intensitas nyeri persalinan antara kelompok dan kelompok tanpa aroma terapi lavender. Didapatkan hasil dengan uji mann- whitney $\rho>0,05$ menyimpulkan bahwa ada perbedaan tingkat nyeri (post) yang bermakna antara kelompok yang diberi aroma lavender dan tida diberi. Rerata tingkat nyeri (post) pada kelompok aroma terapi 5,11 sedangkan kelompok tidak diberi aroma terapi sebesar 13,89.

Dengan demikian pada penelitian ini kedua metode nonfarmakologis dalam upaya mengurangi tingkat nyeri kala I fase aktif persalinan normal sama-sama efektif dan memiliki keunggulan tersendiri. Pemberian aromaterapi ini sesuai dengan teori yang dijelaskan bahwa impuls nyeri dihantarkan saat sebuah pertahanan dibuka dan impuls nyeri dihambat saat sebuah pertahanan ditutup (Manurung, S., 2011).

Kompres hangat dapat menjadikan tubuh terasa rileks karena kehangatan air yang membantu pembuluh darah yang melebar sehingga aliran darah lancar (Sarwono, 2010). Teknik kompres hangat adalaah memberikan rasa hangat pada daerah tertentu dengan menggunakan cairan atau alat yang menimbulkan hangat pada bagian tubuh untuk mengurangi rasa nyeri (Potter dan Perry, 2006).

Tehnik kompres hangat selama proses persalinan dapat mempertahankan komponen sistem vaskuler dalam keadaan vasodilatasi sehingga sirkulasi darah ke otot panggul menjadi homeostatis. Terapi kompres hangat telah terbukti meningkatkan kemampuan ibu untuk mentoleransi nyeri selama melahirkan karenaefek dari panas. Terapis fisik dan profesional kesehatan lainnya telah menggunakan terapi hangat untuk mengurangi berbagai bentuk rasa sakit kronis. Dengan mengkompres di daerah sakrum ibu (punggung bawah) dapat mengurangi nyeri persalinan. Ketika reseptor yang peka terhadap panas dihipotalamus dirangsang, sistem efektor mengeluarkan signal yang memulai berkeringat dan vasodilatasi perifer. Perubahan ukuran pembuluh darah akan memperlancar sirkulasi oksigenisasi mencegah, terjadinya spasme otot, memberikan rasa hangat membuat otot 
tubuh lebih rileks, dan menurunkan rasa nyeri. Hasil penelitian tersebut menunjukkan bahwa kompres hangat efektif dilakukan selama proses persalinan dan merupakan tindakan umum untuk mengatasi nyeri (Brenda, Lane. 2011).

Aromaterapi mawar yang digunakan melalui inhalasi dapat meningkatkan kewaspadaan, meningkatkan daya ingat, meningkatkan kecepatan dalam berhitung. Rosemary merupakan jenis aroma terapi yang dapat digunakan untuk melegakan pikiran dan otot. Aroma yang dihasilkan dapat membantu pikiran lebuh konsentrasi (Maifrisco, 2008).

Selain itu menurut Mackinnon (2004, dalam Riana, 2015) manfaat aromaterapi selain meningkatkan keadaan fisik dan psikologis, aromaterapi dapat memberikan efek relaksasi bagi saraf dan otot-otot yang tegang. Oleh karena itu salah satu cara relaksasi yang digunakan untuk menurunkan kecemasan ialah dengan pemberian aromaterapi.

Relaksasi merupakan salah satu cara untuk mengatasi kecemasan atau stress melalui pengendoran otot-otot dan syaraf. Relaksasi dapat meningkatkan kesehatan secara umum dengan memperlancar proses metabolisme tubuh, menurunkan tingkat agresifitas dan perilaku-perilaku buruk dari dampak stress meningkatkan rasa harga diri dan keyakinan diri, pola pikir menjadi lebih matang, mempermudah dalam mengendalikan diri, mengurangi stress secara keseluruhan, dan meningkatkan kesejahteraan (Riana, 2015).

Menurut penelitian yang dilakukan oleh Rahma (2016) aromaterapi mawar dapat mempengaruhi aktivitas fungsi kerja otak melalui sistem saraf dan dapat meningkatkan produksi masa penghantar saraf otak yang dapat memulihkan kondisi psikis seperti emosi, perasaan, pikiran dan keinginan, selain itu aromaterapi mawar juga dapat memberikan efek relaksasi bagi saraf dan otot-otot yang tegang.
Dari hasil penelitian ini
menyimpulkan eksperimen menunjukkan hasil bahwa ada penurunan intensitas nyeri dalam persalinan. Kedua intervensi ini samasama efektif atau memiliki keefektifan yang setara untuk menurunkan nyeri. Peran bidan dan keluarga sangat berpengaruh dalam mengurangi tingkat nyeri persalinan kala I fase aktif apabila nyeri tidak ditangani dengan baik dapat mempengaruhi proses persalinan dan berdampak kurang baik pada janin. Bidan sebagai pelaksana asuhan kebidanan komprehensif dapat menggunakan metode nonfarmakologis dalam menurunkan intensitas nyeri ibu bersalin.

\section{KESIMPULAN}

Berdasarkan hasil penelitian dan hasil analisa data yang telah dilakukan pada 26 responden ibu bersalin kala I fase aktif di BPM Patmi Hartati Kabupaten Kediri dapat ditarik kesimpulan sebagai berikut:

1. Intensitas nyeri terbanyak sebelum diberikan kompres air hangat pada punggung bagian bawah di BPM Patmi Hartati Kabupaten Kediri adalah skala nyeri 8 dan terendah adalah skala nyeri 5.

2. Intensitas nyeri terbanyak sesudah diberikan kompres air hangat pada punggung bagian bawah di BPM Patmi Hartati Kabupaten Kediri menurun menjadi skala nyeri 7 dan terendah skala nyeri 3 .

3. Intensitas nyeri terbanyak sebelum diberikan aroma terapi mawar di BPM Patmi Hartati Kabupaten Kediri adalah skala nyeri 8 dan terendah skala nyeri 4.

4. Intensitas nyeri terbanyak sesudah diberikan aroma terapi mawar di BPM Patmi Hartati Kabupaten Kediri menurun menjadi skala nyeri 7 dan terendah skala nyeri 3 .

5. Tidak ada perbedaan intensitas nyeri dengan pemberian kompres air 
hangat pada punggung bagian bawah dan aroma terapi mawar pada ibu bersalin kala I Fase Aktif di BPM Patmi Hartati Kabupaten Kediri.

\section{SARAN}

\section{Bagi Tempat Penelitian}

Perlu adanya peran aktif tenaga kesehatan untuk melakukan menejemen penurunan rasa nyeri persalinan dengan menggunakan metode non-farmakologi khususnya penggunaan aplikasi dari kompres panas maupun aroma terapi mawar guna meningkatkan rasa nyaman ibu selama proses persalinan berlangsung.

2. BagiInstitusiPendidikan

Hasil penelitian ini diharapkan dapat digunakan sebagai bahan bacaan yang nantinya dapat memberikan manfaat kepada pembaca khususnya yang berhubungan dengan metode penurunan nyeri persalinan, yaitu metode nonfarmakologi lainnya yang lebih efektif dan efisien selama proses persalinan berlangsung.

3. Bagi Peneliti Selanjutnya

Penelitian selanjutnya diharapkan dapat mengkaji keefektifan dari kedua jenis kelompok perlakuan tersebut dalam menurunkan nyeri pada ibu persalinan kala I fase aktif.

\section{DAFTAR PUSTAKA}

Ardiansyah . 2010. Pengertian Aroma Terapi. http://.www.google.com diakses pada tanggal 2 September 2017 jam: 11.00 WIB.

Bobak, dkk. 2004. Buku Ajar Keperawatan Maternitas. Edisi 4. Jakarta: EGC.

Brenda, Lane. 2011. using warm compresses in labor to reduce pain and tearing. http:// www.suite101.com/content/usingwarm-compresses-in- labor-toreduce- pain-and-tearing-a362421. Diambil tanggal 21 Agustus 2017.
CA, Smith, dkk.
2012. Massage, Reflexology,

other manual methods for

Pain Management In Labor:

An Overview of

Systematic Reviews (Review).

Vol 3: 1- 161.

Dinas Kesehatan Provinsi Jawa Timur. (2014). Profil Kesehatan InonesiaPropinsi Jawa Timur Tahun 2014. http://www.depkes.go.id/resources ldow nload/profil/PROFIL KES PROV INSI_2014/15_Jatim_2014.pdf>. Diakses pada 28 Oktober 2016.

Dwi, Rahma. 2016. Pengaruh Aromaterapi Terhadap Tingkat Kecemasan Pada Ibu Persalinan Kala I di Kamar Bersalin Rsu Kab. Tangerang. Program Studi Ilmu Keperawatan Fakultas Kedokteran Dan Ilmu Kesehatan Universitas Islam Negeri Syarif Hidayatullah Jakarta.

Erawati, Ambar Dwi. 2010. Buku Ajar Asuhan Kebidanan Persalinan Normal. Jakarta : EGC.

H, Baroroh. 2016. Perbedaan Perubahan Tingkat Nyeri Persalinan Normal Antara Kelompok Dengan Dan Tanpa Aroma Terapi Lavender di Lamongan. Program Studi Pendidikan Bidan Fakultas Kedokteran Universitas Airlangga Surabaya.

Harto. 2011. Cara Kerja Aroma Terapi. http://.www.google.com. 3 September 2017 jam: 11.00 WIB.

Hidayat, A.A.A. 2007. Metode Penelitian Kebidanan dan Teknik Analisis Data. Jakarta: Salemba Medika.

http://perpusnwu.web.id/karyailmiah/docu me nts/4149.pdf diakses pada tanggal 29 Desember 2016 jam 20.00 WIB.

http://journal.unipdu.ac.id/index.php/semi nas/ article/viewFile/156/104 diakses pada tanggal 29 Desember 2016 jam 20.00 WIB 
http://stikeskusumahusada.ac.id/digilib/fil es/d isk1/14/01-gdl-nurastutiw673-1- ktinura-i.pdf diakses pada tanggal 16 Januari 2017 jam 10.10 WIB.

http://akbidharapanmulya.ac.id/atm/konte n/ed

itor/samples/jurnal/file_jurnal/t_25 .pdf diakses pada tanggal 1 Februari jam 12.00 WIB.

Kheirkhah M, et all. "Effect of Aromatherapy with Essential Damask Rose Oil on Anxiety of The Active Phase of Labor Nulliparous Women." Journal of Urmia Nursing \& Midwifery Faculty, 2013.

Koensomardiyah. 2009. Minyak Atsiri Vol.07.Jakarta: Trubus Info Kit. http://repository.uinjkt.ac.id/dspac e/bitst ream/123456789/32526/1/Rahma \%20D wi\%20Syukrini\%20\%20FKIK\%20.pdf. Diakses pada tanggal : 21 Agustus 2017 jam : 09.00 WIB.

Manurung Suryani, dkk. 2013. Pengaruh Tehnik Pemberian Kompres Hangat Terhadap Perubahan Skala Nyeri Persalinan Pada Klien Primigravida. Jurnal Health Quality Volume 4 No 1. Halaman 76. Dosen Poltekkes Jakarta Jurusan Keperawatan.

Maryunani, Anik. 2010. Nyeri Dalam Persalinan "Teknik dan Cara Mengatasinya”. Jakarta: TIM.

2011. Keperawatan Maternitas Asuhan Keperawatan INTRANATAL. Jakarta: TIM.

Nur, Rachmitha. 2013. Perbedaan Efektivitas Lama Pemberian Rose Effleurage Terhadap Intensitas Nyeri Kala I Fase Aktif Pada Persalinan Normal Primigravida di Kota Semarang. Jurnal Kebidanan Volume 2 No 4.

Potter, P.A, Perry, A.G. (2005). Buku Ajar Fundamental Keperawatan : Konsep,Proses,
Praktik.Edisi 4.Volume 2. Alih Bahasa : Renata Komalasari,dkk.Jakarta:EGC. (2006). Buku Ajar Fundamental Keperawatan. Jakarta: EGC.

Price, A. Sylvia., \& Wilson, M. L. 2005.Patofisiologi : Konsep Klinis, Proses- Proses Penyakit. Edisi 6 Volume II. Jakarta : EGC.

Ratnasari, Dwi. dkk. 2015. Pengaruh Kompres Hangat Terhadap Nyeri Persalinan Kala I di BPM Wekaden Minogiri Bantul Yogyakarta. Program Studi Kebidanan Jenjang Diploma IV STIKES 'Aisyiyah Yogyakarta.

Rohani. 2011. Asuhan Kebidanan Pada Masa Persalinan. Jakarta: Salemba Medika.

Rubkahwati, et all. 2013. Profil Minyak Atsiri Mahkota Bunga Mawar (Rosa Hybrida L). Surabaya: Kultivar Lokal.

Runiari. 2010. Asuhan Keperawatan Pada Klien dengan Hiperemesis Gravidarum: Penerapan Konsep dan Teori Keperawatan.Jakarta: Salemba Medika.

Saifuddin, Abdul Bari, dkk. 2010. Buku Acuan Nasional Pelayanan Kesehatan Maternal dan Neonatal. Jakarta : YBPSP.

Sari. (2010). Pengaruh penggunaan kompres hangat dalam pengurangan nyeri persalinan kala $i$ fase aktif di klinik hj. Hamidah nasution Medan. http:// www. Research gate.net/publication.

Sondakh, Jenny, dkk. 2013. Asuhan Kebidanan Persalinan \& Bayi Baru Lahir. Jakarta : EMS.

Sulistyawati, Ari, dkk. 2013. Asuhan Kebidanan pada Ibu bersalin. Jakarta : Salemba Medika.

Sumarah. 2009. Perawatan Ibu Bersalin Asuhan Kebidanan Pada Ibu Bersalin. Yogyakarta : Fitramaya. Sugiyono. 2016. Statistika Untuk Penelitian. Bandung: Alfabeta. 
Susilowati, Virgin. 2013. Perbedaan Intensitas Nyeri Persalinan Pada Paturien Primigravida Kala I Fase Aktif yang Diberikan Kompres Panas dan Kompres Dingin di RS Aura Syifa Kabupaten Kediri. Poltekkes Kemenkes Malang Program Studi Kebidanan Kediri, Kediri.

Uliyah, Musrifatul, dkk. 2008. Ketrampilan Dasar Praktik Klinik Untuk Kebidanan. Jakarta: Salemba Medika.

Varney, Helen. 2008. Buku ajar Asuhan Kebidanan Edisi 4. Jakarta: EGC.

Virgin. 2013. Perbedaan Intensitas Nyeri Persalinan Pada Parturien Primigravida Kala I fase Aktif Yang Diberikan Kompres Panas Dan Kompres Dingin Di RS. Aura Syifa Kabupaten Kediri. Poltekkes Kemenkes Malang Program Studi Kebidanan Kediri.

Walsh \& Linda. 2008. Buku Ajar Kebidanan Komunitas. Jakarta: EGC.

Yuliatun, Laily. 2008. Penanganan Nyeri Persalinan dengan Metode Non Farmakologi. Malang: Bayumedia. 